\title{
Analysis of Cash Management of PT XYZ in Karawang
}

\author{
Fithriyyah Nur Afifah S*, Mandra Lazuardi Kitri \\ School of Business and Management \\ Institut Teknologi Bandung \\ Bandung, Indonesia \\ *fithriyyahnas@gmail.com,m.lazuardi@sbm-itb.ac.id
}

\begin{abstract}
PT XYZ is a manufacture of mechanical steel tubes in Karawang, West Java, Indonesia. Due to its Working Capital Management (WCM) on 2014, PT XYZ tried to rearrange the WCM and resulted a well-managed WCM. However, in 20162017, the liquidity ratios of PT XYZ were far above the average companies in the same industry. Indicates PT XYZ hadn't used its current assets or cash efficiently. The researcher decided to use approach method to solve the problem since there's been no study that discusses the required cash for company operations. This method consists of benchmarking, financial ratio analysis, and funding strategy analysis to know the cash required by PT $\mathrm{XYZ}$ and the impact of cash management implementation towards its performance. The total cost of each strategy also proposed to know the most efficient management funding strategy that could be applied by PT XYZ. From the analysis, we found the monthly cash requirement of PT XYZ and the cash management implementation will give an increase to both return on assets and total assets turnover, but a decrease to liquidity ratio. Meanwhile, the funding strategy that's more compatible for PT XYZ is aggressive strategy, because it's less costly compared to the conservative strategy.
\end{abstract}

Keywords: Working Capital Management, cash management, cash requirement

\section{INTRODUCTION}

In the current era of globalization and free trade, all companies are required to compete. This is due to the rapid growth in all business sectors throughout the world, so companies must be able to carry out their business activities better and optimize their resources. The resources owned by company are very important and could determine the ability of the company to be able to compete and continue to develop its business. One important resource that must be managed properly by the company is financial resources. Financial resources are basic company resources whose role is very important in every operational activity of the company, both to finance the daily operations and to finance the company's longterm investment. Following the organization's objective, financial resources could critically finance the strategic organizational resources so the company could expand their business activities [1].

According to Hery [2], company is divided into three types namely manufacturing business, merchandising business, and service business. A manufacturing business is a company that manages raw materials to become finished goods and then sell them to consumers. The company juridically consists of several forms, one of which is a Limited Liability Company (PT). Based on Government Regulations, capital investment in companies in Indonesia is divided into two forms, one of which is Foreign Investment (PMA). This form of corporate investment is based on the origin of investors and majority investment. PMA companies are companies, where its portion of their capital is largely $(75 \%)$ owned and directly invested by foreign private sector. PT XYZ as a manufacturing company, also has a form of investment originating from a foreign country. It was established in 2005 which employs approximately 600 employees divided into twelve departments.

Various activities are carried out by PT XYZ to run the business, and those activities always require funds. The funds used to carry out daily operational activities are called working capital. According to Kamaludin \& Indriani [3], if the working capital was not managed properly, it could give bad impact to the company's operational activities. Due to the importance of working capital in a company, the term of "working capital management" emerged. Working capital management, abbreviated as WCM, is a routine task for financial managers where they should supervise the working capital to ensure the continuity of day-to-day company activities [4]

Practically, PT XYZ also uses working capital management principle to run its' businesses. However, based on the interviews conducted with the Deputy General Manager Finance and Accounting of PT XYZ on 2014, the company generated high profits, but the cash owned was still low and it still had a high loan. Since cash, account receivables, inventory, and account payable or loan are part of working capital [5], the researcher will analyze the working capital management of PT XYZ using financial ratio analysis.

Based on the financial ratio analysis conducted by the researcher, PT XYZ currently face problems related to one element of working capital: cash. On 2016-2017 PT XYZ's current ratio, quick acid-test ratio, and cash ratio have a quite significant gap compared to the average steel pipe industry. It indicates that PT XYZ's cash management was not optimal enough since PT XYZ has an excessive cash compared to the other companies in the same industry. It also indicates that the company might not use the cash efficiently. Therefore, the researcher is encouraged to conduct research about working capital management of PT XYZ, with only one component of working capital: cash. The researcher is also encouraged to 
conduct the research to optimize the cash management of PT $\mathrm{XYZ}$.

\section{METHODS}

The type of research used in this study is quantitative research. From the problem, description, and explanation of current cash management applied by PT XYZ, the researcher will propose efficient strategy of cash management that could be applied by PT XYZ. Therefore, applied research is used in this research since the researcher will use the existing theories to overcome problem faced by PT XYZ.

\section{A. Types of Data}

- Primary Data is data that is obtained by the researcher directly from the data source. In this research, the primary data is obtained by direct research to PT XYZ and consist of the results of interviews directly from the Financial and Accounting staffs of PT XYZ.

- Secondary Data is data or information that is obtained or collected by the researcher from various existing sources and it is usually ready to use. In this research, the secondary data consist of financial report of PT $\mathrm{XYZ}$, financial report of the other companies in the same industry from 2014-2017, and pro forma financial statement of PT XYZ from 2019-2020.

\section{B. Analytical Method}

Since there is no right method that could solve the research problems, the researcher decided to do a quantitative approach method of benchmarking. This research method emphasizes the testing of theories or hypotheses through measuring research variables in numbers and analyzing the data with statistical procedures or with mathematical modeling. Although this approach has been historically formed and based on exact science, in many ways it can also be applied to research from social sciences, where accounting is included [6]. Meanwhile, according to Indrajit [7], benchmarking is an effort of a company or organization to measure its own performance and compare it with a particular benchmark, analyze it, and try to improve the company's or organization's performance towards the analyzed benchmark. There are many ways to set benchmarks, one of them is through financial ratios. Because the financial essentially involved the relation between two accounts or more than two accounts and making the numbers are more substantial, financial ratio are more preferred [8].

By forecasting and benchmarking, the researcher could know the proper cash reserves by PT XYZ in the future. After knowing the proper cash reserves by PT XYZ, the researcher calculated the total cost of funding strategy to find out the most efficient strategy that could be implemented by PT XYZ. At the end of the research, the researcher will compare the financial ratio before the proper cash reserves calculation and the financial ratio after the proper cash reserves calculation to know the impact of the cash management improvement has on the company's performance.
1) Benchmarking the cash ratio, The ratio that will be used as benchmark and to calculate the future cash reserves by PT XYZ is cash ratio. Below is the way to calculate cash by using cash ratio:

$$
\begin{gathered}
\text { Cash Ratio }=\text { Cash or Cash Equivalent }: \text { Current } \\
\text { Liabilities (1) } \\
\text { Cash or Cash Equivalent }=\text { Cash Ratio } \times \text { Current } \\
\text { Liabilities (2) }
\end{gathered}
$$

2) Calculating the total cost of funding strategy, After knowing the monthly proper cash reserves by PT XYZ, the researcher could calculate the total cost of funding strategy. However, we should firstly distinguish the need for permanent and seasonal funding and then we define the aggressive and conservative seasonal funding strategies [4].

a) Permanent versus seasonal funding needs, To calculate the funding requirement of a company, we should know the sales of the company itself. The stability of company's sales made the operating assets investment stable as well, and the company will have a permanent funding requirement. However, the cyclical of company's sales made the operating assets investment vary over time with its sales cycles, and the company will have both seasonal funding requirement and permanent funding requirement for a minimum level of operating assets investment. The formula to calculate the seasonal funding needs are as follows:

\section{Permanent Funding Requirement = Minimum Level of} Operating Asset (3)

\section{Seasonal Funding Requirement $=$ Maximum Level of Operating Assets - Minimum Level of Operating Assets (4)}

b) Aggressive versus conservative funding strategy, The company finances its seasonal demands with short-term debt and its constant requirements with long-term debt under an aggressive funding strategy. And the company will finance its seasonal and permanent requirements with long-term debt if they are under a conservative funding strategy.

Since PT XYZ's sales are cyclic, PT XYZ will have both seasonal funding requirement and permanent funding requirement for its minimum investment in operating assets.

After calculating both the permanent funding requirement and seasonal funding requirement, the next step is gathering required data such as interest rate of short term and long-term borrowing. The last step is to calculate the total cost of each funding strategy.

\section{Total Cost of Aggressive/Conservative Strategy $=$ Cost of Short-term Financing + Cost of Long-term Financing - Earnings on Surplus Balance (5)}

3) Impact of cash management to PT XYZ's performance, After calculating the monthly proper cash reserves by PT XYZ, it can't be denied that PT XYZ performance will also be affected. To measure the impact of the cash management, the researcher will use financial ratio before and after cash management comparison. 
The financial ratios comparison will consist the ratios that is affected by cash management such as liquidity ratio, activity ratio, and profitability ratio.

\section{RESULTS AND DISCUSSION}

\section{A. Benchmarking}

Benchmarking was done by the researcher to get both of current and cash ratio of steel pipe industry. The company will be used as a benchmark in this study if it meets several conditions, namely having a steel pipe or steel tube business field, having complete financial statements from 2014-2017, and having good financial conditions. Based on those conditions, the results are these 4 companies below:

1) PT Steel Pipe Industry of Indonesia Tbk

2) Commercial Metals

3) Tata Steel

4) Olympic Steel

The average cash ratio of steel pipe industry from 20142017 are summarized on the Table 1 . Then, the average cash ratio from 2014-2017 was divided by 4 to get the final average steel pipe industry cash ratio. From the calculation, the researcher got 0.1725 as the average steel pipe industry cash ratio. This ratio will be used to get the proper monthly cash reserved by PT XYZ.

TABLE I. AVERAge CASH RATIO OF SteEl PiPE INDUSTRY FROM 20142017

\begin{tabular}{|c|c|c|c|c|}
\hline \multirow{2}{*}{$\begin{array}{c}\text { Liquidity } \\
\text { Ratio }\end{array}$} & \multicolumn{4}{|c|}{ Year } \\
\cline { 2 - 5 } & $\mathbf{2 0 1 4}$ & $\mathbf{2 0 1 5}$ & $\mathbf{2 0 1 6}$ & $\mathbf{2 0 1 7}$ \\
\hline Cash Ratio & 0.16 & 0.21 & 0.18 & 0.14 \\
\hline
\end{tabular}

\section{B. Forecasting the Cash Required by PT XYZ using Cash Ratio}

To calculate the projected cash or cash equivalent required, the researcher needs the pro forma balance sheet of PT XYZ 2019-2020. After the pro forma balance sheet of PT XYZ was obtained, the researcher multiplies the cash ratio of the average steel pipe industry of 0.1725 with the current liabilities of PT XYZ 2019-2020 to get the amount of cash or cash equivalent required every month. Table 2 and Table 3 shows the cash or cash equivalent required of PT XYZ after calculation using cash ratio:

\section{TABLE II. CASH OR CASH EQUivalent ReQuired By PT XYZ IN 2019}

\begin{tabular}{|l|l|l|l|l|l|l|}
\hline Balance Sheet 2019 & Jan & Feb & Mar & Apr & May & Jun \\
\hline Total Current Liabilities & 131,935 & 133,604 & 72,832 & 68,092 & 71,486 & 94,397 \\
\hline Cash or Cash Equivalent Required & 22,759 & 23,047 & 12,563 & 11,746 & 12,331 & 16,283 \\
\hline $\begin{array}{l}\text { Funding Requirement for Operating } \\
\text { Assets }\end{array}$ & 83,171 & 76,028 & 109,443 & 115,272 & 115,751 & 84,813 \\
\hline Balance Sheet 2019 & Jul & Aug & Sep & Oct & Nov & Dec \\
\hline Total Current Liabilities & 100,601 & 106,805 & 113,009 & 113,009 & 113,009 & 118,637 \\
\hline Cash or Cash Equivalent Required & 17,354 & 18,424 & 19,494 & 19,494 & 19,494 & 20,465 \\
\hline $\begin{array}{l}\text { Funding Requirement for Operating } \\
\text { Assets }\end{array}$ & 107,881 & 117,310 & 118,711 & 136,117 & 144,987 & 143,304 \\
\hline
\end{tabular}

TABLE III. CASH OR CASH EQuivalent REQuired By PT XYZ IN 2020

\begin{tabular}{|l|l|l|l|l|l|l|}
\hline Balance Sheet 2020 & Jan & Feb & \multicolumn{1}{l|}{ lar } & \multicolumn{1}{l|}{ Apr } & \multicolumn{1}{l|}{ May } & \multicolumn{1}{l|}{ Jun } \\
\hline Total Current Liabilities & 71,154 & 72,013 & 68,579 & 56,606 & 56,606 & 56,606 \\
\hline Cash or Cash Equivalent Required & 12,274 & 12,422 & 11,830 & 9,765 & 9,765 & 9,765 \\
\hline $\begin{array}{l}\text { Funding Requirement for Operating } \\
\text { Assets }\end{array}$ & 135,568 & 139,450 & 134,676 & 136,936 & 130,482 & 135,015 \\
\hline Balance Sheet 2020 & Jul & Aug & Sep & Oct & \multicolumn{1}{l|}{ Nov } & Dec \\
\hline Total Current Liabilities & 56,606 & 55,748 & 56,606 & 55,748 & 56,606 & 61,376 \\
\hline Cash or Cash Equivalent Required & 9,765 & 9,617 & 9,765 & 9,617 & 9,765 & 10,587 \\
\hline $\begin{array}{l}\text { Funding Requirement for Operating } \\
\text { Assets }\end{array}$ & 138,782 & 137,695 & 141,661 & 142,952 & 136,425 & 141,790 \\
\hline
\end{tabular}

\section{Aggressive vs Conservative Funding Strategy}

After calculating the monthly cash or cash equivalent required by $\mathrm{PT}$ XYZ for each year, the researcher calculated the monthly funding requirement for operating assets. The result is shown on the Table 4 and Table 5. It is calculated using the formula below:

Funding Requirement $=$ Cash \& Marketable Securities + Inventory + Account Receivables - Account Payable (5)

TABLE IV. Funding REQUIREMENT OF OPERATING ASSETS IN 2019

\begin{tabular}{|c|c|c|c|c|c|c|}
\hline Balance Sheet 2019 & Jan & Feb & Mar & Apr & May & Jun \\
\hline Cash or Cash Equivalent & 22,759 & 23,047 & 12,563 & 11,746 & 12,331 & 16,283 \\
\hline Account Receivable & 69,850 & 64,803 & 68,161 & 74,707 & 75,316 & 60,658 \\
\hline Inventory & 103,674 & 102,958 & ,727 & 5,406 & 3,085 & 0,764 \\
\hline Account Payable & 113,111 & 114,780 & 54,008 & 56,587 & 59,981 & 82,892 \\
\hline $\begin{array}{l}\text { Funding Requirement for Operating } \\
\text { Assets }\end{array}$ & 83,172 & 76,028 & 109,443 & 115,272 & 115,751 & 84,813 \\
\hline Balance Sheet 2019 & Jul & Aug & Sep & Oct & Nov & Dec \\
\hline Cash or Cash Equivalent & 17,354 & 18,424 & 19,494 & 19,494 & 19,494 & 20,465 \\
\hline Account Receivable & 79,977 & 85,656 & 83,308 & 91,831 & 91,819 & 81,624 \\
\hline Inve & 99,647 & 108,530 & 117,413 & 126,296 & 135,179 & 142,719 \\
\hline Account Payable & 89,096 & 95,300 & 101,504 & 101,504 & 101,504 & 101,504 \\
\hline $\begin{array}{l}\text { Funding Requirement for Operating } \\
\text { Assets }\end{array}$ & 107,881 & 117,310 & 118,711 & 136,117 & 144,987 & 143,304 \\
\hline
\end{tabular}

TABLE V. Funding REQUIREMENT OF OPERATING ASSETS IN 2020

\begin{tabular}{|c|c|c|c|c|c|c|}
\hline Balance Sheet 2020 & Jan & Feb & Mar & Apr & May & Jun \\
\hline Cash or Cash Equivalent & 12,274 & 12,422 & 11,830 & 9,765 & 9,765 & 9,765 \\
\hline Account Receivable & 77,643 & 78,231 & 78,407 & 78,460 & 78,476 & 78,480 \\
\hline Inventory & 108,580 & 112,584 & 104,794 & 109,925 & 103,455 & 107,983 \\
\hline Account Payable & 62,929 & 63,787 & 60,354 & 61,213 & 61,213 & 61,213 \\
\hline $\begin{array}{l}\text { Funding Requirement for Operating } \\
\text { Assets }\end{array}$ & 135,568 & 139,450 & 134,676 & 136,936 & 130,482 & 135,015 \\
\hline Balance Sheet 2020 & Jul & Aug & Sep & Oct & Nov & Dec \\
\hline Cash or Cash Equivalent & 9,765 & 9,617 & 9,765 & 9,617 & 9,765 & 10,587 \\
\hline Account Receivable & 78,482 & 78,482 & 78,482 & 78,482 & 78,482 & 78,482 \\
\hline Inventory & 111,748 & 109,951 & 114,626 & 115,207 & 109,390 & 113,075 \\
\hline Account Payable & 61,213 & 60,354 & 61,213 & 60,354 & 61,213 & 60,354 \\
\hline $\begin{array}{l}\text { Funding Requirement for Operating } \\
\text { Assets }\end{array}$ & 138,782 & 137,695 & 141,661 & 142,952 & 136,425 & 141,790 \\
\hline
\end{tabular}

The permanent funding requirement for its minimum level of operating assets, peak seasonal funding requirement of operating assets, and the average funding requirement are calculated to obtain the total cost of aggressive and conservative funding strategy. These calculations are summarized in Table 6 and Table 7. 
TABLE VI. SUMmary TABLE OF FUNDING REQUiREMENT CALCULATION OF PT XYZ IN 2019

\begin{tabular}{|l|r|}
\hline Seasonal Peak Need & 144.987 \\
\hline Minimum Need (Permanent Need) & 76.028 \\
\hline $\begin{array}{l}\text { Peak Seasonal Funding Requirement } \\
\text { (in excess of its permanent need) }\end{array}$ & 68.959 \\
\hline Average Need & 36.705 \\
\hline
\end{tabular}

TABLE VII. SUMMARY TABLE OF FUNDING REQUIREMENT CALCULATION OF PT XYZ IN 2020

\begin{tabular}{|l|r|}
\hline Seasonal Peak Need & 142,952 \\
\hline Minimum Need (Permanent Need) & 130,482 \\
\hline $\begin{array}{l}\text { Peak Seasonal Funding Requirement } \\
\text { (in excess of its permanent need) }\end{array}$ & 12,469 \\
\hline Average Need & 137,619 \\
\hline
\end{tabular}

According to Financial Statements of PT XYZ, the company has loan to PT Bank Mizuho Indonesia. To get the interest rate charged by PT Bank Mizuho Indonesia, the researcher decided to conduct interview with PT XYZ. Based on the interview, the average short-term loan interest rate charged by PT Bank Mizuho Indonesia is about $7.4 \%$ and the long-term interest rate is about $8.6 \%$. PT XYZ is assumed to have $6 \%$ rate of return on marketable securities by investing their surplus balance. This is based on IDR deposits rate of Bank Indonesia that can disrupt the level of company liquidity.

Table 8 shows the total cost of conservative strategy and total cost of aggressive strategy in 2019 and Table 9 shows the total cost of conservative strategy and total cost of aggressive strategy in 2020. The result shows that the total cost of conservative strategy is bigger than the total cost of aggressive strategy both in 2019 and 2020 . It means that the aggressive strategy is less expensive compared to the conservative strategy. However, the decision to choose the strategy that suitable with PT XYZ is in the Deputy General Manager Finance and Accounting of PT XYZ and PT XYZ's hands. Therefore, these total costs will become one of some considerations for PT XYZ in order to choose the best funding strategy that is suitable with PT XYZ.

TABLE VIII. TOTAL COST OF CONSERVATIVE STRATEGY AND AgGressive STRATEGY OF PT XYZ IN 2019

\begin{tabular}{|l|r|}
\hline 2019 (in million IDR) \\
\hline Cost of Short Term Financing & 0 \\
\hline Cost of Long Term Financing & 12.469 \\
\hline Earnings on Surplus Balance & 1.935 \\
\hline Total Cost of Conservative Strategy & $\mathbf{1 0 . 5 3 4}$ \\
\hline \hline Cost of Short Term Financing & 2.716 \\
\hline Cost of Long Term Financing & 6.538 \\
\hline Earnings on Surplus Balance & 0 \\
\hline Total Cost of Aggressive Strategy & $\mathbf{9 . 2 5 5}$ \\
\hline
\end{tabular}

TABLE IX. TOTAL COST OF CONSERVATIVE STRATEGY AND AgGressive StRATEGY OF PT XYZ IN 2020

\begin{tabular}{|l|r|}
\hline 2020 (in million IDR) \\
\hline Cost of Short Term Financing & 0 \\
\hline Cost of Long Term Financing & 12.294 \\
\hline Earnings on Surplus Balance & 320 \\
\hline Total Cost of Conservative Strategy & $\mathbf{1 1 . 9 7 4}$ \\
\hline Cost of Short Term Financing & 528 \\
\hline Cost of Long Term Financing & 11.221 \\
\hline Earnings on Surplus Balance & 0 \\
\hline Total Cost of Aggressive Strategy & $\mathbf{1 1 . 7 5 0}$ \\
\hline
\end{tabular}

\section{Impact of Cash Management on PT XYZ's Performance}

To measure the impact of cash management of PT XYZ with their performance, the researcher decided to create before and after financial ratios of 2019 and 2020. The before financial ratio was made based on the pro forma financial statement of PT XYZ 2019-2020 when the cash amount required had not been calculated. The financial ratios that was used are financial ratios affected by the changes of cash, such as liquidity ratio, activity ratio, and profitability ratio.

TABLE $X$. FINANCIAL RATIO BEFORE AND AFTER THE CASH MANAGEMENT OF PT XYZ IMPLEMENTED

\begin{tabular}{|l|r|r|r|r|}
\hline \multirow{2}{*}{ Financial Ratios } & \multicolumn{2}{|c|}{$\mathbf{2 0 1 9}$} & \multicolumn{2}{|c|}{$\mathbf{2 0 2 0}$} \\
\cline { 2 - 6 } & \multicolumn{1}{|c|}{ Before } & \multicolumn{1}{c|}{ After } & \multicolumn{1}{c|}{ Before } & \multicolumn{1}{c|}{ After } \\
\hline Liquidity Ratio & 3,07 & 2,32 & 7,49 & 3,65 \\
\hline Current Ratio & 1,87 & 1,12 & 5,41 & 1,81 \\
\hline Quick Ratio & 0,92 & 0,17 & 4,01 & 0,17 \\
\hline Cash Ratio & 1,19 & 1,42 & 1,22 & 2,16 \\
\hline Activity Ratio & $9,33 \%$ & $11,14 \%$ & $7,40 \%$ & $13,12 \%$ \\
\hline Total Assets Turnover & \multicolumn{5}{|c|}{ Source: Researcher Analysis. } \\
\hline Profitability Ratio
\end{tabular}

Table 10 shows that all of the liquidity ratios of PT XYZ are declining after the cash management applied and it is caused by the reduction in cash. In 2019, the current ratio was 3.07 and if the cash management was applied, the current ratio will be decrease to 2.32 . In 2020 , the current ratio was decreased from 7.49 to 3.65 due to reduction of cash. The cash ratio of PT XYZ also reduced to 0.17 , in the same level with the steel pipe industry cash ratio.

Because of the reduction of excessive cash of PT XYZ, the significant gap compared to the average steel pipe industry current ratio could be solved. By this, PT XYZ could use the current assets more efficiently to operate their business without having excessive cash. However, the increasing risk of the company to fulfill their short-term obligation should also be considered by PT XYZ.

Meanwhile, the activity ratio of PT XYZ increases because of the reduction of the current assets. Activity ratio, according to Sudana [9], measures the effectiveness and efficiency of a company in managing their assets. The activity ratio that was affected is total assets turnover. This ratio measures the effectiveness and efficiency of a company for using their assets in generating sales. In 2019, the value of PT XYZ's total assets turnover is increasing to 1.42 which means that PT XYZ turn 
However, the decision for using aggressive or conservative funding strategy is depends on the General Manager Finance and Accounting of PT XYZ and the characteristics of PT XYZ itself. By calculating and applying the cash and cash equivalent required by $\mathrm{PT} X Y Z$, the researcher also found out that the company's performance will be affected. It is shown by the changes in financial ratio, such as liquidity ratio, activity ratio, and profitability ratio. By reducing the excessive cash of PT $\mathrm{XYZ}$ in the pro forma balance sheet, the company will be less liquid. However, it will increase the activity ratio i.e. total assets turnover and profitability ratio i.e. return on assets.

\section{REFERENCES}

[1] A. Yusuf, Critical Success Factors for Small Business: Perspectives of South Pacific Entrepreneurs. Journal of Small Business Management, 32 (3), 68-73. 1995.

[2] S.M. Hery, Basic Accounting 1 \& 2. Jakarta: Grasindo. 2017.

[3] K. Kamaludin and R. Indriani, Financial Management "Basic Concept and Application". CV. Mandar Maju. 2012.

[4] L.J. Gitman and C.J. Zutter, Principles of Managerial Finance. England: Pearson Education Limited. 2015.

[5] G. Vural, A. Sokmen, and E. Cetenak, Affects of Working Capital Management on Firm's Performance: Evidence from Turkey. International Journal of Economics and Financial Issues, 488-495. 2012.

[6] S. Efferin, S.H. Darmadji, and Y. Tan, Metode Penelitian Akuntansi Mengungkap Fenomena dengan Pendekatan Kuantitatif dan Kualitatif. Yogyakarta: Graha Ilmu. 2008.

[7] R.E. Indrajit, Benchmark and Benchmarking. Retrieved from indrajit@post.harvard.edu: academia.edu. 2013.

[8] R.S. Schmidgall and A. De Franco, How To Best Use Financial Ratios in Benchmarking and Decision Making in Clubs: Review of the Decade 2003-2012. International Journal of Hospitality \& Tourism Administration. 2016.

[9] I.M. Sudana, Manajemen Keuangan Perusahaan Teori \& Praktik. Penerbit Erlangga. 2011.

[10] M. Tulsian, Profitability Analysis (A comparative study of SAIL \& TATA Steel). IOSR Journal of Economics and Finance, 19-22. 2014. conservative strategy. By applying the aggressive strategy, PT $\mathrm{XYZ}$ could save cost of funding approximately for $\mathrm{Rp}$ 1.279.000.000 in 2019 and for Rp 224.000.000 in 2020 . efficient management cash strategy that could be applied by PT $\mathrm{XYZ}$, the researcher has calculated both the total cost of aggressive strategy and conservative strategy. Based on the result of data analysis, the aggressive strategy is cheaper than 